\title{
sciendo
}

\section{Peculiar encounter of sarcoidosis and solid pseudopapillary tumor of the pancreas}

\author{
CLAUDIA COBILINSCHI ${ }^{1,2}$, CRISTIAN COBILINSCHI ${ }^{2,3}$, IULIANA TRIFAN ${ }^{1}$, CONSTANTIN-IOAN BUSUIOC $^{4}$, \\ RUXANDRA IONESCU ${ }^{1,2}$, DANIELA OPRIȘ-BELINSKI ${ }^{1,2}$
}

\author{
${ }^{1}$ St. Maria Clinical Hospital - Rheumatology and Internal Medicine Department, Bucharest, Romania \\ ${ }^{2}$ Carol Davila University of Medicine and Pharmacy, Bucharest, Romania \\ ${ }^{3}$ Bucharest Clinical Emergency Hospital, Intensive Care Unit, Romania \\ ${ }^{4}$ Matei Balș National Institute for Infectious Diseases, Morphology Department, Romania
}

\begin{abstract}
Objective: Current literature indicates a connection between sarcoidosis and malignancy, prompting advanced screening in uncertain cases. Solid pseudopapillary tumors (SPT) of the pancreas are rare entities that can be confirmed by adding imaging results to immunohistochemistry staining. The aim of this article is to describe a rare association of sarcoidosis and SPT.

Materials and methods: Case report.

Results: A young female patient with no prior medical history presents with shortness of breath and fatigue. The diagnosis of pulmonary and hepatic sarcoidosis is placed upon laboratory and radiographic changes. Intermittent abdominal pain prompts an MRI that shows the presence of a tumoral mass in the tail of the pancreas. Surgical resection of the mass is performed and histological examination indicates a SPT, subsequently confirmed by immunohistochemistry.

Conclusion: This is the third reported case of concomitant sarcoidosis and solid pseudopapillary tumor of the pancreas.
\end{abstract}

Key words: malignancy, pancreas, sarcoidosis, solid pseudopapillary tumor, surgery.

\section{INTRODUCTION}

Sarcoidosis is a systemic disease with incompletely known origin that can affect any organ, including the eyes, skin, joints, heart, kidneys and central nervous system, but it most commonly involves the lungs and the intrathoracic lymph nodes [1]. It is characterized by the presence of non-caseating granulomas confirmed by histopathological examination. Disease can affect both male and female patients, with a slightly female predominance and a peak incidence between 35 to 50 years of age [1].

The most common signs and symptoms include dry cough, dyspnea, enlarged lymph nodes and non-specific constitutional manifestations, such as fever, fatigue and weight loss. However, approximately $50 \%$ of patients can be asymptomatic upon presentation. Other suggestive symptoms include uveitis, arthritis or skin lesions that can be present during disease course [2].

Pulmonary imaging usually reveal bilateral hilar lymphadenopathy, along with reticular opacities in the lung, although in more advanced stages interstitial lung disease or pulmonary fibrosis may be observed [3]. According to chest radiographic abnormalities, disease staging is possible but it does not indicate disease activity of damage [4].

In order to establish the diagnosis of sarcoidosis, a suggestive clinical picture or radiographic finding is necessary, along with histopathological confirmation of non-caseating granulomas. Excluding other possible conditions with similar manifestations, such as infections or malignancies is mandatory.

Solid pseudopapillary tumor (SPT) of the pancreas is an uncommon type of neoplasm, most frequently involving the tail of the pancreas. It was first described in 1959 by Dr. Frantz and later classified by World Health Organization (WHO) as borderline malignant tumor and it usually occurs in young female patients [5]. SPT is characterized by an indolent disease course, favorable long-term prognosis and reduced potential for malignant transformation. Patients are generally asymptomatic or present with minimal symptoms. Complete surgical resection is recommended and is usually curative, although metastatic disease has been observed, particularly 
involving the liver [6]. As of 2015, there were only approximately 800 cases of solid pseudopapillary tumors of the pancreas described in current literature [7].

\section{CASE REPORT}

We report the case of a 33-year-old Caucasian female patient complaining about persistent arthralgia affecting the small joints of the hand, xerophthalmia and intermittent anterior chest pain.

Medical history revealed that the onset of symptoms dated around three years ago when she was diagnosed with pulmonary sarcoidosis. Diagnosis was established after presenting to her general practitioner with moderate dyspnea and fatigue.
The patient was a non-smoker and had no professional exposure to hazardous emissions. She denied having any documented allergies to substances or drugs.

At the time of diagnosis, high levels of angiotensin converting enzyme were recorded and chest X-ray showed bilateral reticulonodular opacities. The computed tomography scan of the chest and abdomen identified numerous pulmonary nodules located in the middle area of both lungs (Figure 1) and hepatosplenomegaly. Tests were negative for infections or malignancy but the bronchoscopy with bronchoalveolar lavage revealed lymphocytic alveolitis, orienting the diagnosis towards sarcoidosis. Pulmonary function tests were within normal range at the time.
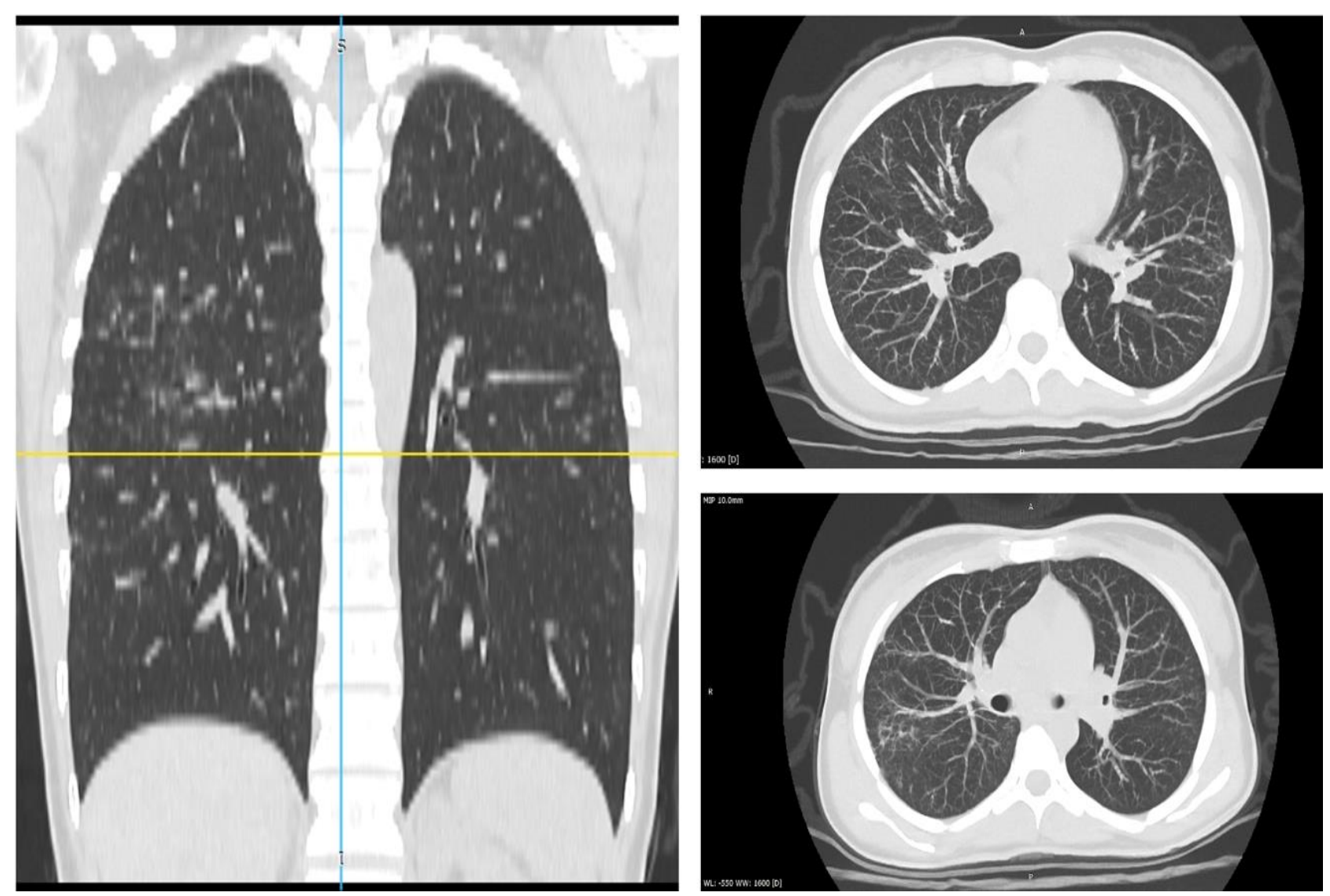

Figure 1.Thoracic CT scan.

Pulmonary CT showing suggestive nodules and areas of reticulonodular changes.

One year later, the patient complained of mild epigastric and right flank pain and loss of apetite but clinical examination showed unremarkable features, except for tenderness in the epigastric region. Cardiopulmonary check-up showed no additional changes from previous check-up visit. During her follow-up imaging scan with MRI, periaortic adenopathies, two subcapsular hepatic nodules and a pancreatic nodule with malignant characteristics were described (Figure 2). 


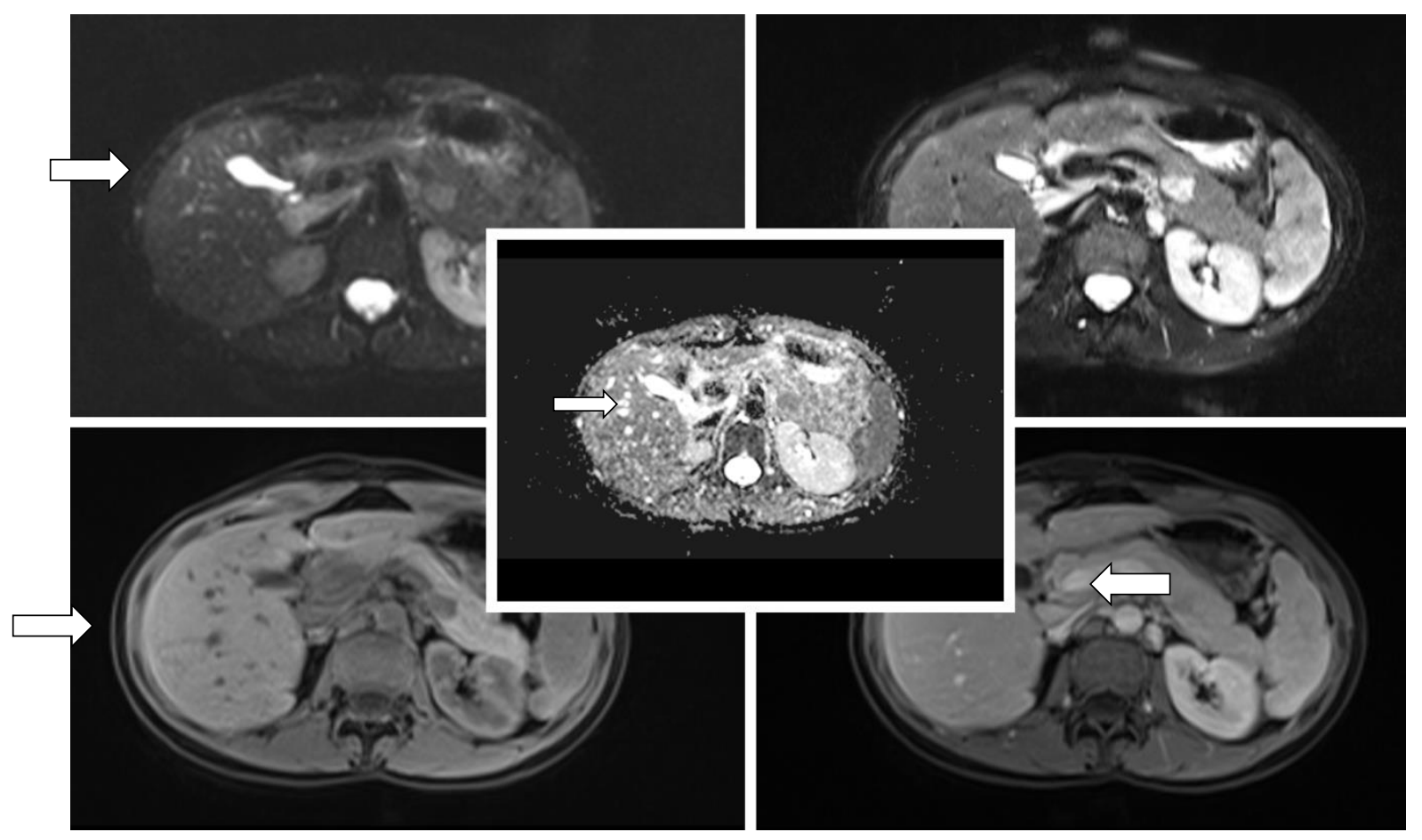

Figure 2. Abdominal MRI.

MRI showing both hepatic and pancreatic nodules, with T2-weighted and diffuse-weighted imaging (DWI) hypersignalling and hyposignal in apparent diffusion coefficient (ADC).

Tumor markers like cancer antigen (CA) 19-9 and carcinoembryonic antigen (CEA) were within normal limits. She was later admitted in the gastroenterology department for further investigations and a fine-needle-aspiration (FNA) procedure confirmed the presence of solid pseudopapillary tumor. The result of the FNA conducted further corporeo-caudal pancreastectomy with spline and splenic vessel preservation. Hepatic nodule biopsy in the second segment was also achieved.

The histopathological report showed chronic granulomatous inflammatory lesions, nonnecrotizing compatible with sarcoidosis in the hepatic lesion and splenic ganglia, while the pancreatic piece indicated solid pseudopapillary neoplasm with pT2pN0 staging, as detailed below (Figure 3).
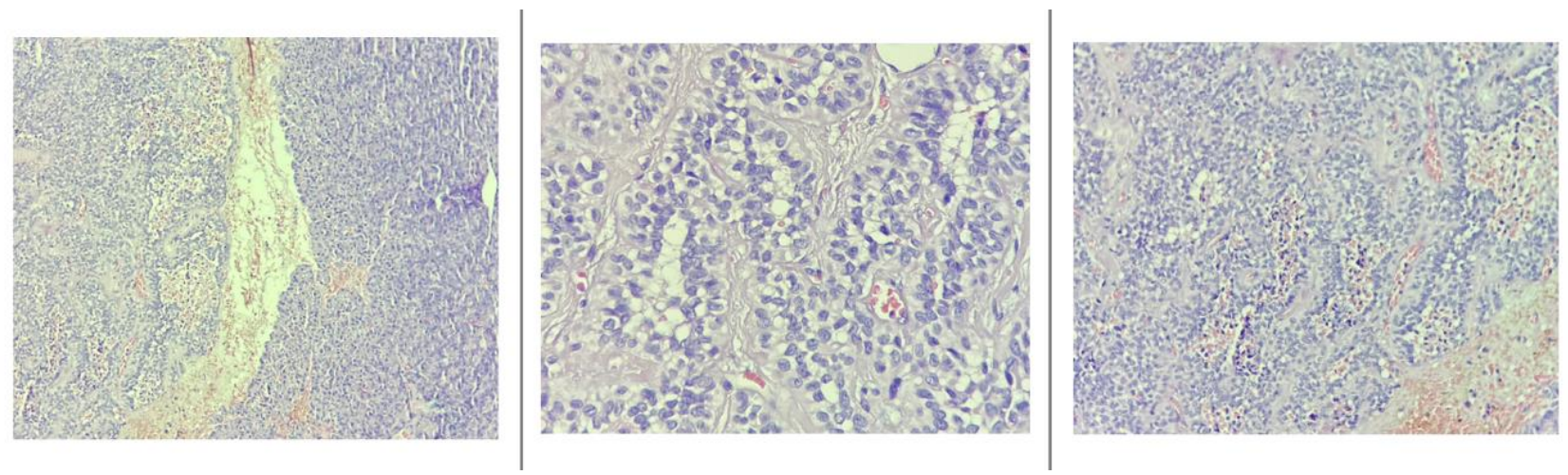

Figure 3. Histological features of pancreatic lesion.

Anatomopathological examination confirming an epithelioid tumor (10X right) adjacent to the normal pancreatic parenchyma (10x left). The tumor is composed of poorly cohesive cells distributed around blood vessels resulting in a pseudopapillary architecture (20x). Hemorrhagic areas are also present. Tumor cells have large amounts of pale eosinophilic cytoplasm with perinuclear vacuoles, bland nuclei, inconspicuous nucleoli and grooves (40X). 
Further immunohistochemistry (IHC) testing confirmed the preliminary pancreatic description, with positive beta-cathenin in tumoral cell nuclei, positive CD10 cells and positive progesterone receptors (PR) while cytokeratine (CK)-7, chromogranin A ( $\mathrm{CgA})$ and synaptophysine (SPY) were negative.

Three months after primary surgery, an abdominal drain tube was inserted under ultrasound guidance due to development of pancreatic fistula, with favorable subsequent evolution.

The patient underwent oral glucocorticoid therapy with regular dose adjustments according to her pulmonary disease status. No new organ involvement occurred. Current joint and eye complaints were investigated but no objective change suggestive of sarcoid complications were noted. Ultrasound evaluation of the parotid and submandibular glands, as well as the hand joints found no abnormal features.

Patient will be further monitored by a multidisciplinary team including a pneumologist and an oncologist, to assess any significant clinical or imaging changes in patient's disease course.

Sarcoidosis has previously been linked to malignancy particularly with regard to lymphoma, melanoma, lung, liver, cervical and gastric neoplasms [8]. The onset of sarcoidosis can precede that of cancer or it can develop as a paraneoplastic manifestation in patients with established malignancy. Some patients with solid tumors present "sarcoid-like" reactions, usually involving the skin and regional lymph nodes [9].

Solid pseudopapillary tumors are rare epithelial neoplasms that occur mainly in young female patients with a slight predilection for those with Asian and African American origin. SPT resemble other pancreatic tumors like neuroendocrine tumors or pancreatoblastomas, since they have common imaging and pathologic features. Immunohistochemical advanced tests might clear the diagnosis [10].

Clinical presentation in SPT is non-specific and its presence might go unnoticed until routine imaging is performed. Abdominal pain or distension, nausea or vomiting can be the sole indicators of SPT [6].

As the presented case, the young female patient complained of intermittent abdominal pain but no other alarming symptoms were noted until imaging was performed.

Laboratory tests are non-specific and tumoral markers might be within normal limits.
Helpful imaging techniques are the ultrasound which can identify a heterogeneous well-defined mass, CT or MRI revealing both solid and cystic areas within the mass.

Histologically, SPT can have a capsule and tumoral cells form a pseudopopapillary pattern with areas of necrosis and hemorrhage. IHC tests are typically positive for vimentin, CD10, CD56, CD99, and alpha-1 antitrypsin (AAT) and negative for E-cadherin [11].

The patient in the case report tested positive in IHC stains for PR. Published data in the literature suggests that negative PR staining is a factor for poor prognosis and predicts unsatisfactory disease outcome.

Pancreatic malignancies usually have a poor long-term prognosis, especially because of indolent course and being identified in advanced stages [12]. However, SPT which represent less than $2 \%$ of exocrine pancreatic tumors, have a better outcome and the majority resolve through surgery alone. If complete resection is successful, survival rate at five years is as high as $97 \%$. The risk of recurrence is situated at around $10-15 \%$ of patients [13].

SPT exhibits a risk of malignant transformation of $15 \%$. A single-center study in 53 SPT patients indicated that $18.9 \%$ cases were malignant with vascular infiltration, parenchymal, perineural or adjacent organ invasion [14]. However, no case presented exacerbated nuclear atypia or high mitotic rate. The same publication by Song et al. suggests that incomplete capsule of SPN might be an indicator of malignancy and prognosis predictor [5].

The association between SPT and concurrent sarcoidosis is extremely rare, with only two other published cases in the literature, as described below.

A case report published in 2020 describes a 34-year-old female patient who was admitted for right abdominal pain with tenderness upon palpation, loss of appetite over the last two months [15]. Preliminary laboratory tests were unremarkable, including tumoral markers, while the chest X-ray displayed enlarged lymph nodes in the mediastinum. The CT scan confirmed the lymph nodes, pleural effusion and a tumor with solid and cystic components in the neck of the pancreas. Infections were excluded and biopsy of the mediastinal lymph nodes revealed the presence of non-caseating granulomas, pointing towards sarcoidosis. Meanwhile, the biopsy of the pancreatic 
tumor resembled a SPT, later confirmed by IHC stains. Surgical resection was decided with favorable discharge of the patient. Case report highlights the rarity of the concurrence of the two entities [15].

The second similar case report was published in Egypt by Tamer et al. and describes the case of a 44-year-old female patient with history of abdominal pain and limb edema. The abdominal CT scan reported a large soft tissue mass in contact to the pancreatic tail, while the thoracic area had multiple enlarged hilar, aortopulmonary lymph nodes. Bronchoalveolar lavage and lymph node biopsy confirmed sarcoidosis, while resection of the abdominal pass indicated SPT on histological exam [16].
Sarcoidosis is a rare, multisystem disease that usually involves the lungs and intrathoracic lymph nodes but may affect any organ and can sometimes occur concomitantly with malignancy. Solid pseudopapillary tumors of the pancreas are uncommon, generating little to no symptoms and they usually have a favorable outlook following surgical removal. The coexistence of these two clinical entities is unusual and has seldomly been described, this being the third reported case in the existing literature. Therefore, the aim of this case report is to raise awareness of the rare but possible association in order to facilitate a timely diagnosis.

Obiectiv. Literatura descrie o legătură între sarcoidoză și malignitate, recomandând screening avansat în cazuri incerte. Tumorile pseudopapilare solide $(S P T)$ ale pancreasului sunt entități rare care pot fi confirmate prin coroborarea aspectului imagistic cu testarea imunohistochimică. Scopul acestui articol este de a descrie o asociere rară de sarcoidoză multi-organ și SPT.

Materiale și metode. Raportare de caz.

Rezultate. O pacientă tânără fără antecedente medicale prezintă dificultăți de respirație şi oboseală. Diagnosticul de sarcoidoză pulmonară și hepatică se pune pe baza modificărilor de laborator și radiografice. Durerea abdominală intermitentă conduce la efectuarea unui IRM care confirmă prezența unei mase tumorale în coada pancreasului. Se efectuează rezecția chirurgicală a masei și examenul histologic indică un SPT, confirmat ulterior prin imunohistochimie.

Concluzie. Acesta este al treilea caz raportat de sarcoidoză concomitentă și tumoră pseudopapilară solidă a pancreasului.

Correspondence to: Cristian Cobilinschi, 52 M. Andreescu Str, Bucharest, Romania, 00765018776, cob_rodion@yahoo.com Acknowledgements: none.

Conflict of interest disclosure: The authors declare no conflict of interest.

\section{REFERENCES}

1. GRUNEWALD, J., GRUTTERS, J. C., ARKEMA, E. V., SAKETKOO, L. A., MOLLER, D. R., MÜLLER-QUERNHEIM, J., Sarcoidosis Nat. Rev. Dis. Prim. 2019512019 ; 5(1): 1-22.

2. ARKEMA, E., GRUNEWALD, J., KULlBERG, S., EKLUND, A., ASKLING, J., Sarcoidosis incidence and prevalence: a nationwide register-based assessment in Sweden Eur. Respir. J. 2016; 48 1690-1699.

3. VAGAL, A. S., SHIPLEY, R., MEYER, C. A., Radiological manifestations of sarcoidosis Clin. Dermatol. 2007; 25(3): 312-325.

4. Kaiser, Y., Eklund, A., and Grunewald, J., Moving target - shifting the focus to pulmonary sarcoidosis as an autoimmune spectrum disorder Eur. Respir. J. 2019 ; 54:182153.

5. SONG, H., DONG, M., ZHOU, J., SHENG, W., ZHONG, B., GAO, W., Solid Pseudopapillary Neoplasm of the Pancreas: Clinicopathologic Feature, Risk Factors of Malignancy, and Survival Analysis of 53 Cases from a Single Center Biomed Res. Int. 2017; 2017:5465261.

6. DIN, N. U., RAHIM, S., ABDUL-GHAFAR, J., AHMED, A., AHMAD, Z., Clinicopathological and immunohistochemical study of 29 cases of solid-pseudopapillary neoplasms of the pancreas in patients under 20 years of age along with detailed review of literature Diagn. Pathol. 2020; 15(1): 1-12.

7. ZALATNAI, A. KIS-ORHA, V., Solid-pseudopapillary neoplasms of the pancreas is still an enigma: a Clinicopathological review Pathol Oncol Res 2020; 26(2): 641-649.

8. COHEN, P. R. KURZROCK, R., Sarcoidosis and malignancy Clin. Dermatol. 2007 ; 25(3): 326-333.

9. EL JAMMAL, T., PAVIC, M., GERFAUD-VALENTIN, M., JAMILlOUX, Y., SÈVE, P., Sarcoidosis and Cancer: A Complex Relationship Front. Med. 2020; 7857. 
10. LAW, J. K., AHMED, A., SINGH, V. K., AKSHINTALA, V. S., et al., A systematic review of solid-pseudopapillary neoplasms: Are these rare lesions? Pancreas 2014; 43(3): 331-337.

11. ERRÁEZ-JARAMILlO, P. J. ORTIZ-HIDALGO, C., The histological and immunohistochemical diagnosis of solid pseudopapillary neoplasm of the pancreas and its differential diagnosis Rev Esp Patol 2019; 52(3): 178-179.

12. TJADEN, C., HASSENPFLUG, M., HINZ, U., KLAIBER, U., et al., Outcome and prognosis after pancreatectomy in patients with solid pseudopapillary neoplasms Pancreatology 2019; 19(5): 699-709.

13. ABE, A., OHISHI, Y., MIYAZAKI, T., OZONO, K., et al., "Microcystic pattern" should be recognised as part of the morphological spectrum of solid-pseudopapillary neoplasm of the pancreas Histopathology 2018; 72(2): 216-226.

14. JENA, S. S., RAY, S., DAS, S. A. P., MEHTA, N. N., YADAV, A., NUNDY, S., Rare Pseudopapillary Neoplasm of the Pancreas: A 10-Year Experience. Surg. Res. Pract. 2021; 20217377991.

15. SHAH, I., MEHTA, H., ANKLESARIA, A., KADKHODAYAN, K., Solid Pseudopapillary Tumor of the Pancreas in a Patient With Sarcoidosis: A Rare Combination Cureus 2020; 12(5): e8340.

16. TAMER, ELHADIDY, ELSAYED, NESREEN, M., et al., Sarcoidosis associated with pseudopapillary pancreatic tumor Int. J. Case Reports Images 2015; 6(11): 690-693.

Received $17^{\text {th }}$ December 2021 